DOI https://doi.org/10.18551/rjoas.2018-06.23

\title{
THE INFLUENCE OF BRANDING STRATEGY AND MARKET SHARE ON FORMING BRAND EQUITY OF MIE SEDAAP
}

\author{
Handayani Christifani \\ Business School of Bogor Agricultural University, Bogor, Indonesia \\ E-mail: christifanih@gmail.com
}

Nurrochmat Dodik R.

Department of Forest Management and Business School, Bogor Agricultural University,

Bogor, Indonesia

E-mail: dnurrochmat@apps.ipb.ac.id.com

\author{
Wijayanto Hari \\ Department of Statistics, Faculty of Mathematics and Natural Sciences, \\ Bogor Agricultural University, Bogor, Indonesia \\ E-mail: hari ipb@yahoo.com
}

\begin{abstract}
PT. Wings Foods is one of leading companies in Indonesia. In 2003, PT. Wings Foods released its flagship product in the field of food and beverage namely Mie Sedaap. The presence of Mie Sedaap was considered successful in instant noodle market and successfully managed to get its market segmentation. It also attained positive response of instant noodle consumers that a few years after its presence, Mie Sedaap was able to reach the second position of share market behind its biggest competitor, Indomie. Understanding the branding strategy is the right way to form the brand strength in the market and to lead the market share. This study discussed the influence of branding strategy and market share on forming brand equity and was conducted in Depok. The purposive sampling technique was used as the method of gathering non probability samples.
\end{abstract}

\section{KEY WORDS}

Branding strategy, market share, brand equity, instant noodles.

Rapid business competition and technological developments no longer focus on quality, price and promotion competition, but brand competition. A company that has a strong brand is considered to have excellent advantages and be able to stimulate consumers and create new markets in order to achieve competitive advantage that will more easily launch a variety of marketing strategies to excel in the competition. A company that is aware of a brand realizes that the brand becomes an identity and becomes an added value in selling its products. Brand is defined as the term, sign, symbol, or design and its combination intended to identify the goods or services. The brand is considered to provide a stimulus to the minds of consumers, so it makes sense to understand that brands not only make our marketing target choose us in this competent market but also make our marketing prospects see us as the only one that can provide solutions to their needs or problems. Branding strategy becomes one of ways to increase market share. Brand strategy is a brand management that aims to manage all elements of the brand in relation to consumer attitudes and behaviors; it can also be interpreted as a communication system that organizes all point contacts with a product or service or organization itself to stakeholders and directly support business strategy completely. The presence of Mie Sedaap in 2003 was strongly supported by Wings Corporation to expand its product in the field of food and beverages. Mie Sedaap that is supported by Wings Food has a target to meet customer satisfaction and to make Mie Sedaap products successful in international market in the future. Mie sedaap is considered to be successful in Indonesian market and to successfully enter the market of instant noodles. 
Many consumers currently switch to and set their mind on Mie Sedaap products. Here is the data of TOP of Mind by last usage (2014).

Table 1 - TOP of Mind by Last Usage of Some Brands of Instant Noodle

\begin{tabular}{lllll}
\hline \multirow{2}{*}{ TOP Of Mind by Last Usage } & \multicolumn{3}{c}{ Brands } \\
\cline { 2 - 5 } Indomie & Indomie & Mie Sedaap & Supermie & Sarimi \\
\cline { 2 - 5 } Mie Sedaap & $\mathbf{9 2 . 5 0 \%}$ & $12.80 \%$ & $42.10 \%$ & $29.80 \%$ \\
Supermi & $2.60 \%$ & $\mathbf{7 6 . 3 0 \%}$ & $5.80 \%$ & $3.60 \%$ \\
Sarimi & $1.10 \%$ & $1.60 \%$ & $\mathbf{5 0 . 1 0 \%}$ & $0.00 \%$ \\
Lain-lain & $0.20 \%$ & $2.10 \%$ & $0.00 \%$ & $\mathbf{6 4 . 8 0 \%}$ \\
\hline
\end{tabular}

Sources: $h$ ttp://www.topbrand-award.com

The above data can be explained that respondents who lastly consumed Indomie when mentioning instant noodle brands, $2.60 \%$ of respondents firstly mentioned Mie Sedaap brand, respondents who lastly consumed Mie Sedaap when mentioning instant noodle brands, $76.30 \%$ of them mentioned Mie Sedaap brand firstly, respondents who lastly consumed Supermie, $50,10 \%$ of them mentioned Mie Sedaap brand firstly. Then respondents who lastly consumed Sarimi, $64.80 \%$ of them mentioned Mie Sedaap brand firstly. Data of Top of mind can suggest the strength of Mie Sedaap brand in the consumers' mind.

The launch of Mie Sedaap products was said to be successful, proven by several awards it received just like the Roy Morgan Customer Satisfaction Award 2015 as Instant Noodle of The Year. This certainly made a positive impact on the development of Mie Sedaap, that during the last five years Mie Sedaap was able to keep its rank in the second after the market leader of instant noodles in Indonesia. According to TOP brand awards data, it explained that Mie Sedaap brand had been strengthening. The following is Table 2 TOP Brand awards from 2013 to 2017.

Tabel 2 - TOP Brand Awards

\begin{tabular}{lllll}
\hline \multirow{2}{*}{ Years } & \multicolumn{5}{c}{ Brands } \\
\cline { 2 - 5 } & Indomie & Mie Sedaap & Sarimi & Supermi \\
\hline 2017 & $80.00 \%$ & $\mathbf{1 0 . 8 0 \%}$ & $3.40 \%$ & $3.20 \%$ \\
2016 & $78.70 \%$ & $\mathbf{1 2 . 5 0 \%}$ & $3.60 \%$ & $3.00 \%$ \\
2015 & $75.90 \%$ & $15.90 \%$ & $2.70 \%$ & $2.20 \%$ \\
2014 & $75.90 \%$ & $14.40 \%$ & $2.80 \%$ & $2.20 \%$ \\
2013 & $80.60 \%$ & $13.50 \%$ & $2.10 \%$ & $0.60 \%$ \\
\hline
\end{tabular}

Sources: http://www.topbrand-award.com

The TOP brand awards were conducted through three main stages: the last instant noodle brand that was consumed, the instant noodle brand that is often consumed and the last instant noodle brand that firstly appears in the consumer's mind. The result showed there was an increase in brand strength of Mie Sedaap from year to year.

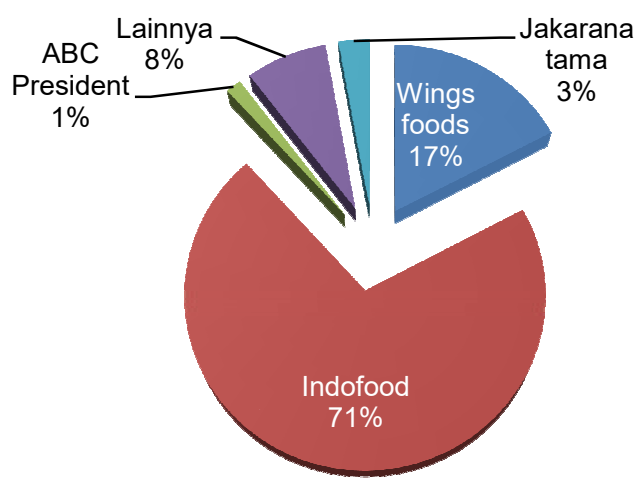

Figure 1 - Market Share of Instan Noodle in Indonesia in 2006 
According to data released by SWA magazine (2004), the largest competitor of market share was indomie in 2002 of $90 \%$. However, since the presence of Mie Sedaap in the instant noodle market, the market share of Indomie has been declining and until the end of 2016 the market share of Indomie decreased to $70 \%$. Here is a figure of instant market share of instant noodles in Indonesia in the third quarter of 2016.

Based on the data above, the market share position of Mie Sedaap in 2006 only ranked in the second after the biggest market share, which is Indomie. Also, seen from the TOP brand data until 2016 Mie Sedaap was only able to stay in its position and did not experience a continuous brand increase and in 2017 Mie Sedaap decreased by two percent compared to the previous year. This should be considered by P.T Wings Food with its flagship product of Mie Sedaap to run an active and efficient strategy to make rapid development.

\section{LITERATURE REVIEW}

Brand is an identity of a product. Almost all products use brand to differentiate their products with competitors' products, even the brand becomes a unique symbol strategy to attract consumers. The term brand itself came from an ancient language that means to burn, the ancient Nurse using a burned stamp to mark his livestock (Keller 1998). Brand itself is a distinguishing name and symbol (such as a logo, stamp or packaging) that aims to characterize the goods or services of a particular sales group (Aaker 1997).

Branding strategy. Branding strategy is an activity that manages all elements that aims to form a brand (Schultz and Barnes 1999). Successful brand management is to build an echoed voice in marketing practices, a business with a strong market orientation that has segmented the target market and sustained customer behavior based on that segment is the best position to build a meaningful brand identity for its target customers. The first step in the development of brand identity is specificying the target market. Without this specification, the brand identification process quickly weakens into an internal process that only spins around in product features rather than benefits that customers can obtain (Sumawan 2009).

According to Gelder (2005) a brand strategy included brand positioning, brand identity, brand personality and brand communication (Schultz and Barnes 1999).

Market share. Market share is an indicator of what a company does to its competitors with the support of changes in sales (Sumarwan et al., 2010). Meanwhile, according to Assauri (2001) Market share is the amount or the total market area that can be controlled by a company that is usually expressed as a percentage. There are several ways to increase market share, including: developing marketing policies, product development, product line development, and business expansion (acquisition or merger). Market share is part of the market that can be achieved by a company that can be used as one indicator of performance of a company's marketing. According to Sumarwan et al. (2011) components of the marketing mix that can be responded positively by consumers include:

Product awareness Measures the level and changes of customers' knowledge, perceptions, beliefs, interests and customers' behavior towards purchases.

Product attractive/ Attitudes related to customer responses to brands.

Price acceptable The acceptable price of the consumer is the price that corresponds to the purchasing power of the consumer and corresponds to the product benefits offered.

Product available Components of marketing strategies that are run with the aim of ensuring the ease of consumers to get products in various market locations.

Service experience Service experience, both at the time of purchase and after purchase (after sales service).

Brand equity. According to Aaker (1991) as it corresponds to the definition of brand equity which is a set of assets and liabilities, it is grouped into five categories. Here is a figure 2 Concept of Brand Equity (Aaker 1991). 


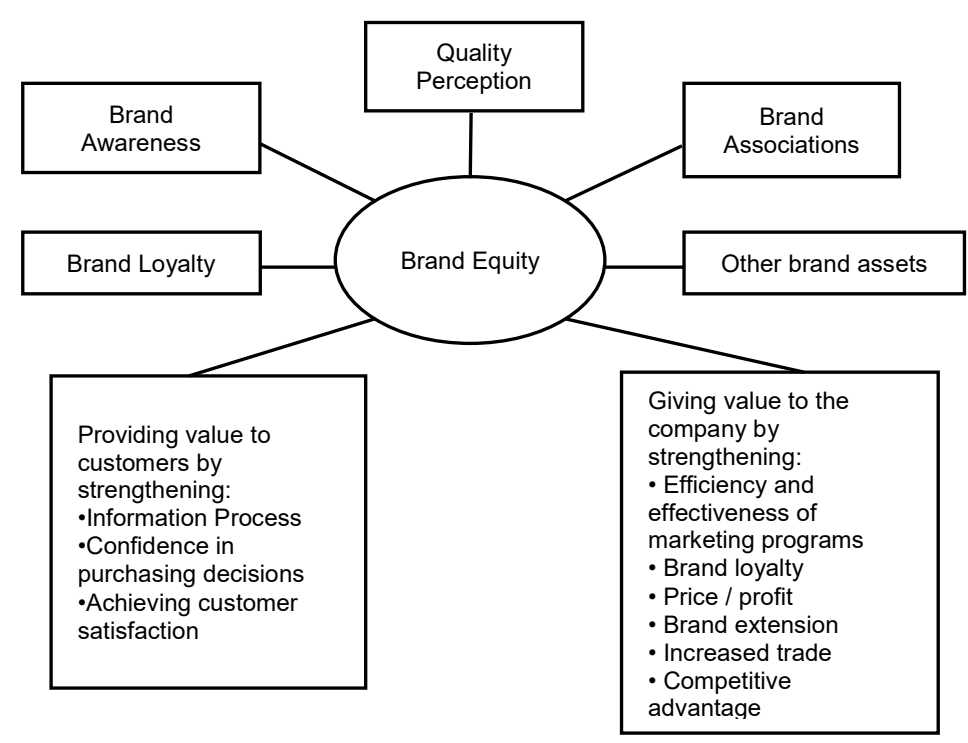

Figure 2 - Concept of Brand Equity (Aaker 1991)

According to Aaker (1991) there are five categories of brand equity: brand awareness, brand association, perceived quality, brand loyalty and other proprietary brand assets. The first to fourth category is the main element of brand equity, while the fifth category that is other proprietary brand asset will be directly affected by the quality of the four main elements. The concept of brand equity shows that brand equity can create value for both the customer and the company.

\section{METHODS OF RESEARCH}

The study was conducted in July to November 2017 in Depok. The quantitative approach was used in the study supported by qualitative approach. The primary and secondary data were used in the study. Primary data were data taken from the first source, from face-to-face interviews with the respondents. While the secondary data were from literature materials, and other printed media as well as literatures relevant to the study. Population in this study was the community who consume instant noodles. Criteria of respondents as the samples in this study are people who consume instant noodles at least 3 times a week. The number of samples taken from society (consumer) used rule of thumb from Structural Equation Modeling (SEM). According to Hair et al. (2006) the number of samples required for each estimated parameter variable of exogenous and endogenous construct is five to ten observations. This study used 145 people as the samples.

\section{CONCEPTUAL FRAMEWORK}

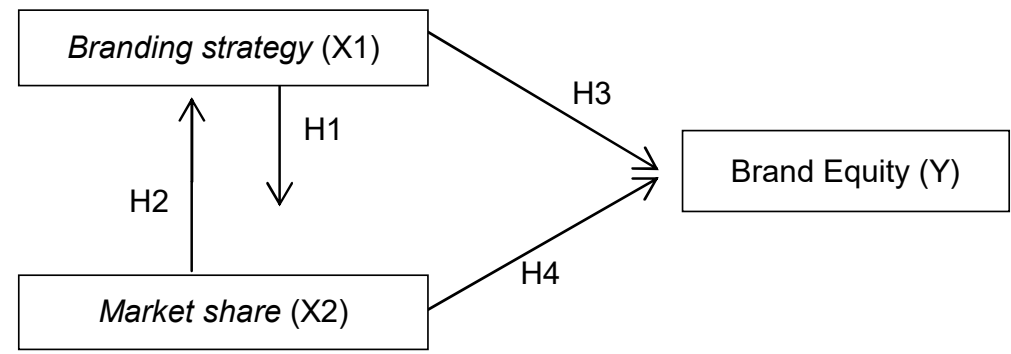

Figure 3 - Conceptual Framework 
The formulation of this framework of the study was based on literature study to explain the relationship between independent variables and the dependent variables shown in Figure 4. The flow of framework was analyzed to see the influence of branding strategy and market share on forming brand equity. The variables used were branding strategy, market share and brand equity.

Based on the conceptual framework above, the proposed research hypotheses are:

$\mathrm{H} 1$ : Branding strategy has a positive and significant influence on Market Share;

$\mathrm{H} 2$ : Market Share has a positive and significant influence on Branding Strategy;

H3: Branding strategy has a positive and significant influence on Brand Equity;

$\mathrm{H} 4$ : Market Share has a positive and significant influence on Brand Equity.

\section{RESULTS AND DISCUSSION}

The number of respondents in this study is 145 respondents. The data was tabulated with a descriptive approach based on characteristics of sex, occupation, income, and age. Characteristics of respondents show the diversity of respondent data representing this study. In this study, it was found that 62.8 percent were female and 37.2 percent were male. This indicates that women have an influence in deciding the purchase. The result of this study is in accordance with a study conducted by Cosmin (2012) that showed that women tend to be a pioneer in decision making. Generally, women, who more often do activities to shop for household purposes as well as the shopping doer regardless of whether these women will consume these products, have a role to bring product information. Based on the type of work of 165 respondents, it was found that the largest profession of respondents is housewife, 56.6 percent of the total respondents. According to Engel et al. (1994) the type of consumers' job greatly influences their lifestyle. The lifestyle of a housewife, which is the dominant respondent, has a role in determining the choice for consumption pattern of their family member.

The highest average monthly income of respondents was in the range of Rp. 3,000,000 - Rp.7,000,000 as many as 49 respondents, then as many as 41 respondents had the amount of income with an average of < Rp.3,000,000. Respondents with an average expenditure smaller > Rp. 2,000,000 tend to have the smallest frequency (below 10). According to Sumarwan (2011) the amount of income will show the amount of purchasing power of a consumer. The purchasing power will show the number of products or services normally purchased by a consumer and consumed by a consumer and all members of the family.

The most dominant age of respondents was $26-35$ years old, 44.8 percent of the total percentage of respondents.

Fit Stage of Overall Model. This fit stage is concerned with the initial model of structural equation before estimating. The model is designed based on previous theories, literatures and researches. Table 3 shows the overall model results.

Table 3 - Overall Model Results

\begin{tabular}{llll}
\hline & & Models & \\
\hline Goodness-of-Fit & Cut-off Value & Hasil & Kecocokan \\
\hline RMR (Root Mean Square Residual) & $\leq 0,05$ atau $\leq 0,1$ & 0.041 & Good Fit \\
RMSEA (Root Mean square Error of Approximation) & $\leq 0,08$ & 0.073 & Good Fit \\
GFI (Goodness of Fit) & $\geq 0,90$ & 1.00 & Good Fit \\
AGFI (Adjusted Goodness of Fit Index) & $\geq 0,90$ & 1.00 & Good Fit \\
CFI (Comparative Fit Index) & $\geq 0,90$ & 1.00 & Good Fit \\
NFI (Normed Fit Index) & $\geq 0,90$ & 1.00 & Good Fit \\
Relative Fit Index (RFI) & $\geq 0,90$ & 1.00 & Good Fit \\
\hline
\end{tabular}

It can be seen (Table 3 ) that the criteria of RMSEA produced a value of 0.073 that can be interpreted that the model is fit. The use of other goodness of fit criteria on the results of data processing ie GFI, CFI, NFI, AGFI, and RFI produced value $>0.90$ which means the model is good fit. Likewise with the measurements criteria of other goodness of fit. RMR 
produced a value of 0.041 , which means it is good model (good fit). These overall model results were used in the next stage that was the compatibility of the measurement model. Here is figure 4 the Overall Models of the Result of Structual Equalition Modeling.

Relationship between Branding strategy and Indicators. Based on SEM calculations, there are several indicators that reflect dimension in expressing branding strategy; each indicator has different contribution value in reflecting branding strategy variable. Criteria that are significant are those with loading factor value $>0.5$ and t-count $>1.96$ (Hair et al 2006).

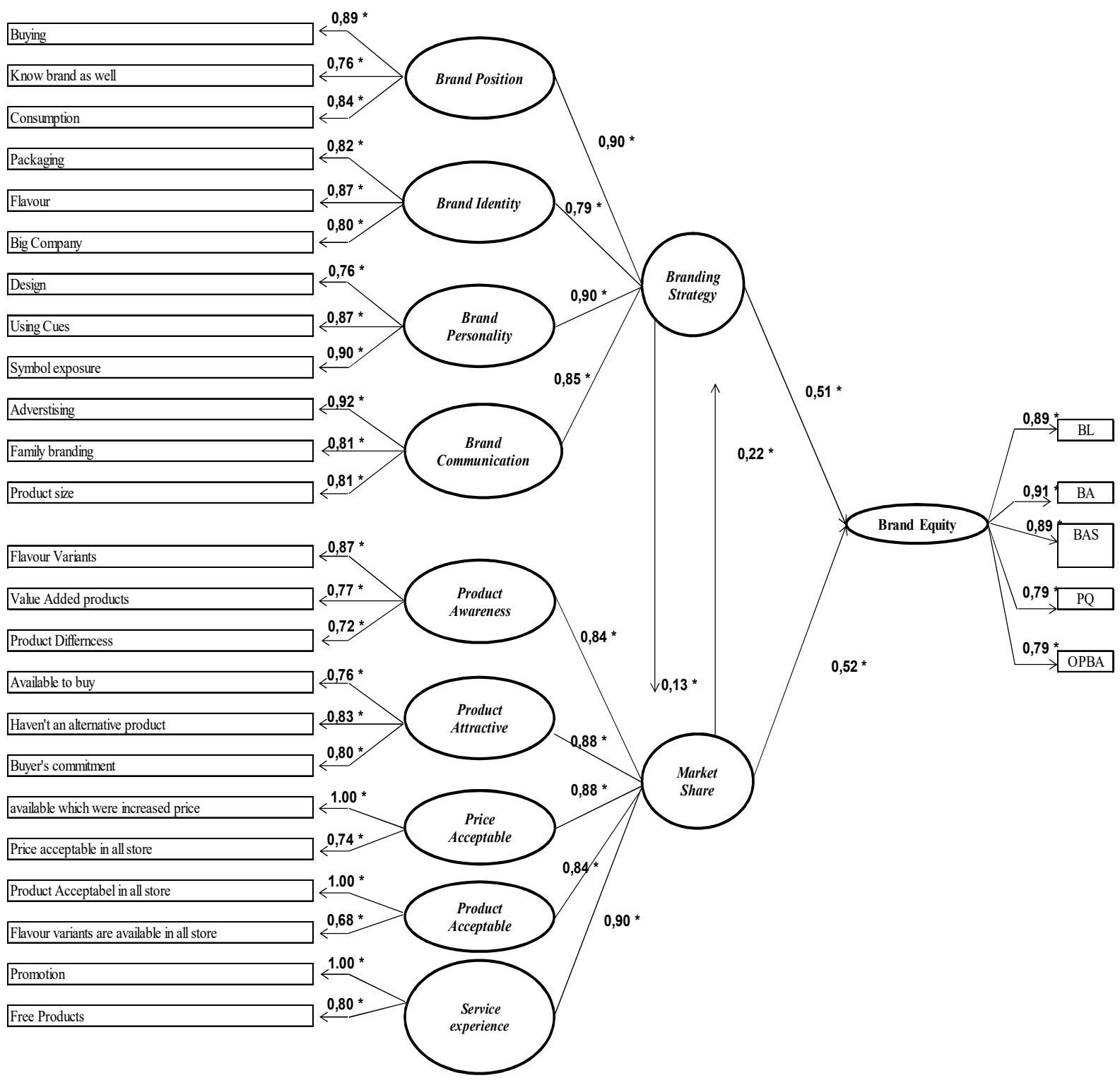

${ }^{*} t$ - count significance

Figure 4 - Overall models of the Result of Structural Equation Modeling

There are three indicators in branding strategy that reflect the dimension in branding strategy. The largest to the smallest contribution indicators on the dimension of brand positioning are purchase (loading value 0.89), consumption (loading value 0.84 ), and being familiar (loading value 0.76). The purchase has the greatest contribution so it can be interpreted that a brand is able to form the minds of consumers to purchase the products. The purchase can also be interpreted that the message that the company has delivered to the product through the placement of the product position can be well received by consumers, that is by buying the product (Mie Sedaap). Three indicators of brand identity are 
packaging (loading value 0.82), flavour (loading value 0.87 ), and large company (loading value 0.80 ). The flavour indicator has the highest loading factor value explaining that when a consumer likes the characteristic flavour of a product (Mie Sedaap), it can positively impact on current and long-term purchasing decisions, while in this study packaging indicators and large company have less loading values.

The latent variable of brand personality is constructed from three indicators that describe the product of the brand (Mie Sedaap) that are design, using cues, symbol exposure. The contribution levels from the highest to the smallest are symbol exposure (loading value 0.90), using cues (loading value 0.87), and design (loading value 0.76). Symbol exposure is the use of symbols that aims to facilitate consumers to recognize a brand through a visual display of the symbol rather than a word or phrase used, while using cues is the use of cues, guides or directions aimed at directing consumers to the product. It is known that the largest indicator contribution of brand communication is advertisement (loading value 0.92), then family branding and size which have same loading value factor (loading value 0.81). Advertisement as the largest loading value factor can explain that advertising is one of the most influenceive ways to inform brands (Mie Sedaap).

Relationship between Market Share and Indicators. There are four dimensions that make up market share that are product awareness, product attractive, price acceptable, product acceptable and service experience that each dimension has an instrument with different loading factor value; the criteria that is significant are those with loading factor value $>0.5$ and t-count $>1.96$ (Hair et al. 2006). In the dimension of product awareness, there are three indicators, namely flavour variant, added value of the product and product difference. These three indicators have different loading value factors on the dimension of product awareness. The highest to the smallest contribution are the flavour variant (loading value 0.87 ), the added value of the product (loading value 0.77 ) and the product difference (loading value 0.72). The flavour variants have the greatest contribution to brand positioning variables; having different flavour variants and being innovative give a good impact in positioning its products. In product attractive variable, there are three indicators that have different loading factor value. The three indicators are purchasing ability, no other product alternatives and customer commitments. The highest to the smallest contribution value of this indicator are the no other product alternatives (loading value 0.83 ), the customer commitment (loading value 0.80 ) and the purchasing ability (loading value 0.76 ). Consumer interest in a product can be represented on the indicator no other product alternative. When consumers are interested and active in a product, they must have a loyalty to the product.

The price acceptable variable consists of two indicators that are to still purchase even if the price is raised (value loading 1.00) and to purchase with the determining price (loading value 0.74). Purchasing with determining price has great contribution value to price acceptable variable. It means that the consumers who receive the price will still purchase the product at any price. Furthermore there are two indicators on product acceptable that are product availability (value loading 1.00) and the availability of flavour variants (loading value 0.68). The product availability has the greatest contribution tno product acceptable that means product availability can be a consumers' reason to purchase Mie Sedaap products. The product availability is the main thing for consumers to support the ease in the purchasing process. There are two indicators on the service experience variable or it can be interpreted as interesting experience obtained by the consumers which is promotion indicators (loading value 1.00 ) then free product (value loading 0.80 ). This explains that when purchasing a product, the promotion of the product is such an excitement and provides a memorable experience for consumers to consider making a purchase again later.

Relationship between Brand equity and Indicators. In the brand equity variable, there are five indicators, namely brand loyalty, brand awareness, brand association, perceived quality and other proprietary brand assets. Each indicator has different contribution value; it can be seen from the loading factor value.

The five indicators have different contributions, the level of contribution can be seen from the loading factor value and t-count. The higher value possesed by an indicator the greater contribution to the variable influenced. The greatest to the smallest contribution are 
peak of mind (loading value 0.93), sibling brand (loading value 0.89), loyal consumers (loading value 0.87 ), loyalty (loading value 0.79 ) and quality (loading value 0.75 ). The greatest indicator is peak of mind that explains that if the brand of Mie Sedaap is already attached to the peak of consumer's mind, wherever the consumer is, the Mie Sedaap brand will be always remembered by the consumer's mind and form the power of Mie Sedaap brand. Subsequently, when consumers has positioned the Mie Sedaap brand at the peak of his mind, in some way it will affect the decision process in the purchase.

\section{HYPOTHESIS OF STUDY}

The test results of the structural model of the study can be seen in figure 5 . Based on the results obtained, it suggests that the relationship between variables is significant or influential on brand equity by considering the value of t-count and path coefficients.

Figure 5 shows the overall t-count value, the following is table 4 that show the hypothesis result of branding strategy, market share and brand equity.

The test of branding strategy variable to Brand equity. Based on test results, that can be seen in Table 12, the t-test value of branding srategy was 9.48 with a coefficient of 0.51 . This result stated $\mathrm{HO}$ was rejected ( $\mathrm{t}$-count $>\mathrm{t}$-table) so that branding strategy affects brand equity. According to sumarwan (2009) a successful brand management is to build an echoed voice in marketing practices, without which the process of identifying the brand will weakens into an internal process that only spins around in product features rather than benefits that customers can obtain. This result is in line with a study by Radityani (2006); the relationship between brand strategy done by Goota Japanes Charcoal Grill and Cafe and brand equity received by consumer, that there is positive causal relationship between brand strategy (brand positioning, brand identity, brand personality, brand communication) and brand equity. There are two indicators that have a major contribution in the formation of branding strategy variable on Mie Sedaap products that are symbol exposure (loading value 0.90) and advertisement (loading value 0.92).

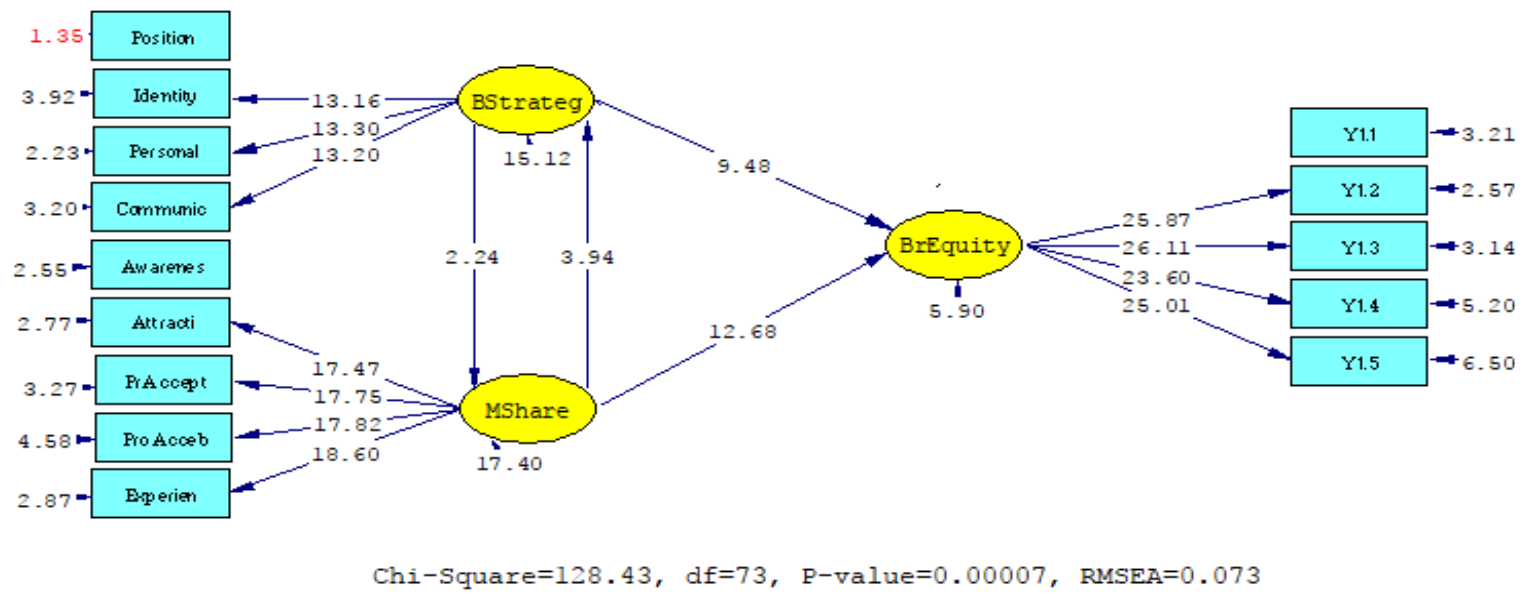

Figure 5-Overall t-count values

Table 4 - Hypothesis results of branding strategy, market share and brand equity

\begin{tabular}{llll}
\hline Correlations & Coeficient & t-count values & Conclusion \\
\hline Branding strategy $\rightarrow$ Brand equity & 0.51 & 9.48 & Significant \\
Market share $\rightarrow$ Brand equity & 0.52 & 12.68 & Significant \\
Market share $\rightarrow$ Brand Strategy & 0.22 & 3.94 & Significant \\
Branding strategy $\rightarrow$ Market share & 0.13 & 2.24 & Significant \\
\hline
\end{tabular}

Test of Market Share on Brand Equity. There is a significant influence of market share on brand equity (t-count 12.68) and (coefficient value 0.52) Market share shows the market brand strength in terms of actual purchasing behavior of consumers. There are three 
indicators that can reflect in building a market share of Mie Sedaap which are to still purchase even if the price is raised (loading value 1.00), product availability (loading value 1.00 ), and promotion (loading value 1.00).

According to Sudomo (2013), brand equity affects the purchase decision. Similarly, Victor's study (1985) argued that "residual brand equity measured by lagged market share". The study explained the brand strength factors was taken into account by the market share.

Test of Market share of Branding strategy. The test result of market share to branding strategy shows that there is a significant relationship between branding strategy and market share (t-count 3.94) and (coefficient value 0.22). The test of market share to branding strategy. The results of previous study by Pleshko and Heiens (2012) showed that there is a significant relationship between the performance of a company's market share and the strategy applied by the company. The results also showed that one of the strategy contigencies has a significant relationship to market share.

Test of Branding strategy to Market share. The value of t-count of branding strategy to market share is 2.24 with coefficient 0.13 shows the influence of branding strategy to market share. This result is in line with Pleshko and Heiens' study (2012). The results suggest that at least six of seven combinations of strategic contingencies have a significant relationship to the market share. This study also reveals that the market share performance of a firm is related to the number of strategies applied by the firm between market position and various strategic components of the company. According to Victor (1985) market share is the goal of marketing strategy in which there is information using factors of porter performance one of them is strategy.

Managerial Implications. Based on the results of the study and data processing on the influence of branding strategy and market share in establishing brand equity of Mie Sedaap, the managerial implications can be seen in table 5 .

Table 5 - Influence of branding strategy and market share in establishing brand equity

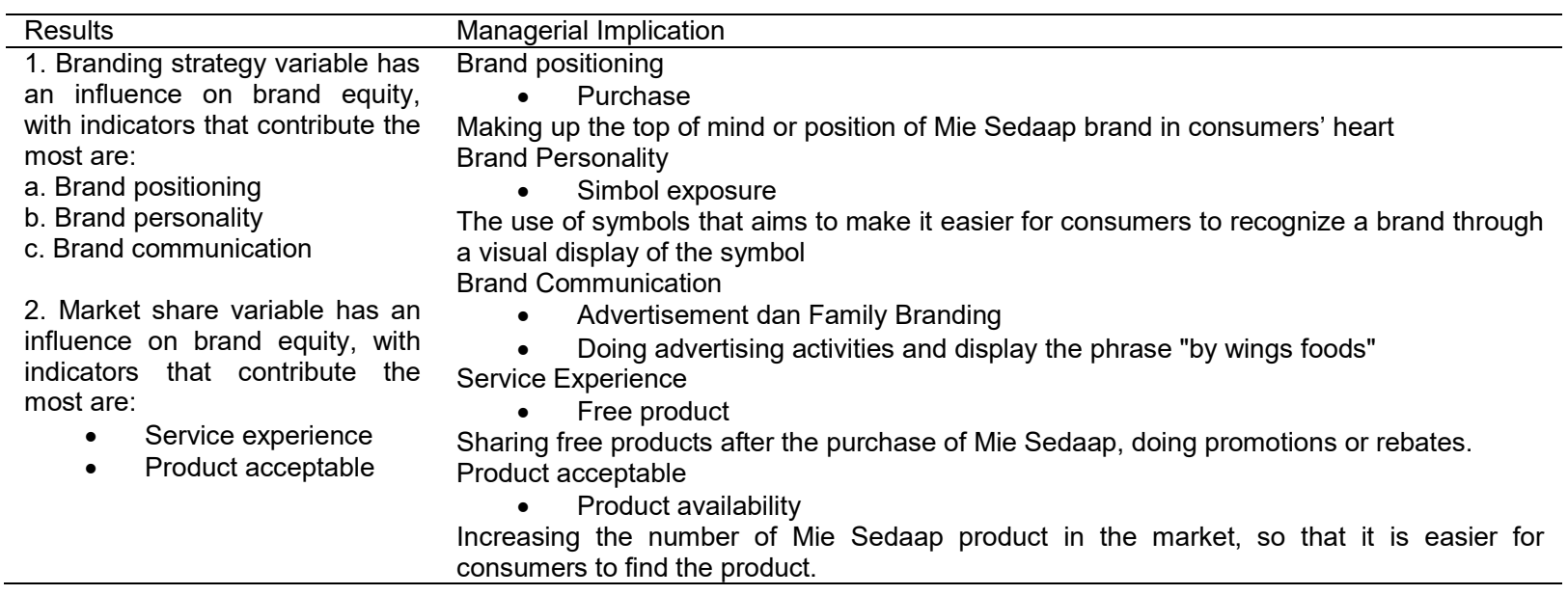

Table 5 describes the implications formulated is in accordance with the indicators that have the greatest contribution, first on the purchasing side when the consumer buys the Mie Sedaap product, the marketer (the company) must maintain the position of Mie Sedaap brand at the top of the consumer's heart. In the application of simbolexposure, marketers are required to communicate about Mie Sedaap easily and directly to the top of community's feeling. A display in the form of images and visual certainly can facilitate Mie Sedaap brand accepted and embedded in the socienty's heart. Both official and partnership agencies can be used by the marketers to do a direct promotion to community, promotions are done by distributing free products after purchase such as buying five free one bowl. The product availability becomes one of the products that has the greatest contribution, the great number of products in the market can facilitate society to get Mie Sedaap products, even when becomes an alternative product, Mie Sedaap products can be easily found by the community. 


\section{CONCLUSION}

The conclusions obtained in this study are each variable has a direct relationship and related to each other. This study suggests that there is a direct influence of branding strategy on market share, market share on brand equity, as well as an influence of branding strategy on market share, and vice versa. One thing that must be considered in forming brand equity of Mie Sedaap is how the company applies the branding strategy; one of the indicators that play an active role is the symbol exposure, which is the use of symbols that aims to facilitate consumers to recognize the brand. The availability of Mie Sedaap products is the most significant indicator in the market share variable that the great number of products in public can show the power of the brand.

\section{RECOMMENDATIONS}

It should be considered as a suggestion based on this study that there is an indicator that can form brand equity of Mie Sedaap, which is the branding strategy. In formulating a strategy, Mie Sedaap is suggested to consider the influenceive ways, two of which are the use of symbols that aims to facilitate consumers to recognize the brand and advertising as one of ways to communicate the brand.

\section{REFERENCES}

1. Aaker DA. 1991. Managing Brand Equity: Capitalizzing on the Value of A Brand Name. New York (NY): The Free Press.

2. Aaker DA.1997. Manajemen Ekuitas Merek. Memanfaatkan nilai dari suatu merek [Brand Equity Management. Utilize the value of a brand]. Jakarta (ID): Mitra Utama.

3. [Anonim] Produk produk detail [Products detail] [internet]. [Accessed on 2017 July 20]. Available at http://www.wingscorp.com/content/product

4. Apipudin. 2014. Menghitung level of loyalty dengan data top brand [Calculates the level of loyalty with top brand data] [Internet]. [Accessed on 2017 July 9]. Available at http://www.top brand- award.com larticle /menghitung_level of_loyalty_dengan_data_top_brand.html.

5. Assauri S. 2001. Analisis Strategy Indomie Sebagai Brand Market Leader [Analysis of Indomie Strategy as Brand Market Leader]. Jakarta (ID): Institution publisher of University of Indonesia.

6. Bloomberg LP. 2017. Indofood kuasai $70 \%$ pasar mie instan Indonesia [Indofood controls $70 \%$ of Indonesia instant noodle market] [internet]. [Accessed on 2017Juli 11]. Available at http://en.databoks.katadata.co.id/ data publish /2017 /01/30/ indofood-kuasai-71-pasarmi-instan-indonesia.

7. Crainer S, Dearlove D. 2003. The Ultimate Book of Business Brands: Insight from The World's 50 Greatest Brands. United Kingdom (UK): Capstone.

8. Cosmin DA. 2012. Factors that influence consumer purchasing decision of organic food [thesis]. Rumania (ROU).Alexandru loan Cuza University of lasi.

9. Darmawan, Syarifah H, Asnawati. 2016. Perbandingan equitas merek Indomie dan mie Sedaap [Comparison of brand equity of Indomie and Mie Sedaap]. Jurnal Manajemen 8:(2):122-131.

10. Engel JF, Blackwell RD, Miniard PW. 1994. Perilaku Konsumen [Consumer behavior]. Sixth Edition. Jakarta (ID): Binarupa Aksara.

11. Freed D.2006. Manajemen Strategi.Ed ke-10, translator. Ichsan S, editor. Stefanus R. Translated from Strategic Management Concept and Cases.10th Ed. Jakarta (ID): Salemba empat.

12. Gelder SV.2005. Global Brand Strategy. London (UK): Kogan Page.

13. Hair JF, BlackWC, BabinBJ, AndersonRE, TathamRL. 2006. Multivariate data Analysis. Sixth Edition. New Jersey (US): Prentice Hall. 
14. KotlerP.2002.Manajemen Pemasaran [Marketing Management]. Millennium Edition Volume 2. Jakarta (ID): PT. Prenhallindo.

15. Kotler, Keller KL. 2009. Manajemen Pemasaran [Marketing Management]. Edition 13 Volume 1. Jakarta (ID): Erlangga

16. Keller KL. 1993.Conceptualizing, measuring and managing customer-based brand equity.Journal of Marketing 57 (1): I-22.

17. Keller KL.1998. Strategic Brand Management: Building, Measuring and Managing BrandEquity. New Jersey (US): Prentice Hall International Inc.

18. Mowen C, John MN. 2002. Perilaku Konsumen. [Consumer behavior] Jakarta (ID): Erlangga.

19. Muzzaqi A, Fauzi A, Suyadi I. 2016. Pengaruh kesadaran merek kesan kualitas, asosiasi merek, dan loyalitas merek terhadap ekuitas merek [The influence of brand awareness, quality impressions, brand associations, and brand loyalty on brand equity]. Jurnal Administrasi Bisnis. 31(1): 26-34.

20. Pleshko LP, 2012. The market share impact of the fit between market leadership efforts and overall strategic aggressiveness. Journal of Business and Economics Research. 3(3): $1-15$.

21. Radityani A. 2006. Hubungan brand strategy yang dilakukan Goota Japanes Charcoal Girll dan cafe [The relationship between brand strategy by Goota Japanes Charcoal Girll and cafe]. Jurnal Managemen Perhotelan 3(1):43-56.

22. Ridgon EE, Ferguson JR CE. 1991. The performance of the polychoric correlation coefficient and selected fitting function in confirmatory factor analysis with ordinal data. Jurnal of Marketing Research. 28(4): 491-497.

23. Schultz, 1999.Strategic Brand Communication Campaign.Chicago (NTC): Bussines Books.

24. Salelaw, Gashaw TAS. 2016. The impact of sales promotion on brand equity: The Case of Brewery Industry. Journal of Marketing and Consumer Research. 22(24):68-81.

25. Susanto, Hilmawan W.2004.Power Branding Membangun Merek Unggul dan Organisasi Pendukungnya [Power Branding Building a Superior Brand and its Supporting Organizations]. Jakarta (ID): PT. Mizan Publika Jakarta

26. Sudomo ST. 2013. Pengaruh equitas merek terhadap keputusan pembelian (studi kasus konsumen Pepsodent di Kabupaten Bantul) [The influence of brand equity on purchasing decisions (case study: Pepsodent consumers in Bantul District)]. Journal management Business Administrasi 1(2):66-74

27. Sugiyono. 2010. Metode Penelitian Pendidikan Pendekatan Kuantitatif, Kualitatif, dan R\&D [Educational Research Method Quantitative, Qualitative, and R \& D Approach]. Bandung (ID): Alfabeta.

28. Sumarwan U. 2011.Perilaku Konsumen: Teori dan Penerapannya Dalam Pemasaran [Consumer Behavior: Theory and Its Application In Marketing].Bogor (ID): Ghalia Indonesia.

29. SumarwanU, Djunaidi A, Alivian, Rocky S, Saryoni JA, Budidarmo RR, Rambe S.2009. Pemasaran Strategik. Strategi Untuk Pertumbuhan Perusahaan Dalam Penciptaan Nilai Bagi Pemegang Saham [Strategic Marketing. Strategy for Corporate Growth In Value Creation For Shareholders]. Jakarta (ID): Inti Prima Promosindo.

30. Sumarwan U. et al. 2010. Pemasaran Strategik Perspektif Value - Based Marketing\&Pengukuran Kinerja [Strategic Marketing of Value-Based Marketing Perspective \& Performance Measurement]. Bogor (ID): IPB Press. Bogor.

31. [TBA] Top brand award [Internet]. [Accessed on 2017 July 9]. Available at http://www.topbrand-award.com.

32. Wijanto SH. 2008. Structural Equation Modeling Dengan Lisrel 8.8 Konsep dan Tutorial [Structural Equation Modeling With Lisrel 8.8 Concepts and Tutorials].Yogjakarta (ID).

33. Wings foods [Internet].[Accessed on 2017 July 9]. Available at http://www.wingscorp.com/

34. Wiwik M.2012. Brand management through long-term strategy ot the strengthening of brand equity. Jurnal Management review spring 3(1):102-124. 
35. VictorJC.JR.1985.The net present value of market share.Journal of Marketing. 49(1):4963.

36. [YLKI] Yayasan Lembaga Konsumen Indonesia. Sehat ada ditangan kita [Indonesian Consumers Foundation. Healthy is in our hands]. 2014. [Internet]. [Accessed on 2017 July 9]. Available at http://ylki.or.id/2014/09/sehat-ada-di-tangan-kita/

37. Yuanzhong. 2005. A study on the relationship between public relations and brand strategy [thesis]. China (CN).Kristianstad University.

38. Zumar D.2006.Adu kuat brand awareness indomie vs mie sedaap selama 5 tahun terakhir 2011-2015 [Brand awareness competition of Indomie vs Mie Sedaap for the last 5 years 2011-2015]. [Accessed on 2017 July 9]. Available at http://www.marsindonesia.com/ 